\title{
Implementing Peer Assessment to Improve the Writing Ability of the Second Year Students of SMP Negeri 44 Muaro Jambi
}

\author{
Abdul Khalim \\ SMP Negeri 19 Muaro Jambi \\ Correspondence email: abdulkhalim.threekids@gmail.com
}

\begin{abstract}
This research report is written to promote the use of peer assessment in EFL classrooms at SMP level. On the basis of a preliminary study done at SMPN 44 Muaro Jambi and the growing interest of the use of alternative assessment strategies led to the idea to conduct a study to implement an applicable and appropriate strategy of peer assessment to improve the writing ability of the second year students of SMPN 44 Muaro Jambi. The researcher designed a classroom action research (CAR) study. It beg an with a try out. A plan was then made in order the procedures implemented could facilitate the second year students of SMPN 44 Muaro Jambi to handle peer assessment properly and improve their ability in writing a descriptive paragraph as well. It was continued by implementing the plan, observing and evaluating or reflecting. The findings showed that the appropriate strategy of peer assessment in writing instructions to improve the students' ability in writing a descriptive paragraph requires teachers to follow procedures; telling the purpose of conducting peer assessment, encouraging collaborative work, encouraging impartial assessment, giving clear and detailed guidelines, building students' self confidence to write and assess, encouraging students' self confidence to write and assess, and ensuring follow up tasks.
\end{abstract}

Keywords: peer assessment; collaborative works; writing skill.

\section{INTRODUCTION}

As one of the productive skills that should be developed in instructional activities, writing is considered being the most complicated one for students. Writing is a personal act in which writers take ideas or prompt and transform them into self initiated topics (O'Malley \& Pierce, 1996). In addition, writing also requires the mastery of mechanical aspects of written expression i.e., handwriting, spelling, punctuation, capitalization and format (Wallace, 1978). Therefore, it is difficult for students to produce a good piece of writing, particularly, if it is done in a foreign language like English.

To examine students' performance and progress in writing, teachers need to carry out an assessment, but most teachers find that it is not an easy job. They acknowledge that teaching and assessing writing is boring and time consuming. One of the reasons why the teaching of writing seems to be neglected is due to assessment problems (Mukminatien, 1997: 1).

In perceiving the statement above, Stiggins (1994: 15) states that assessments and teaching can be one and the same. They do not have to be one and the same but they can be when we want them to be. Sometimes it is all right to conduct an assessment merely as status check not linked to an immediate instructional use. However it is also all right to regard assessment as a powerful instructional tool.

In these recent years there is a change of interest in alternatives to traditional forms of assessment in education. Even though traditional forms of assessment can provide valid measurement of students' performances, they often fail to provide detailed information about what students know or can do in the area they have learned. Therefore, in order to see students' growth and problems in learning, an alternative assessment needs to be implemented (Richards \& Renandya, 2002)

Alternative assessment is a new term known as an authentic assessment. It is typically authentic because it is based on activities that represent classroom and reallife settings. It is the multiple forms of assessment that reflect student learning, achievement, motivation, and attitudes on instructionally relevant classroom activities (O'Malley \& Pierce, 1996). The procedures of an alternative or authentic assessment include a variety method for assessing students' performances in more authentic circumstances including portfolio assessment, self-assessment, peer-assessment, etc.

It is very common we find assessment in writing done by teachers only. They typically define the topics of writing, establish the criteria for evaluating and grade it by themselves. The teacher-centred approach for writing assessment is done by most teachers as an original transmission model of learning and instruction. In this case, students' participation is not involved. They do their writing assignment without being aware of the criteria how their work would be assessed, and as a result, they never know whether their work has met the criteria or not. They even do not always understand or pay attention to the content of their teacher's response to their writing. Therefore, the teachers need to explore different ways or strategies in writing assessment and involve students in assessing their own works.

In supporting the idea above, O'Malley and Pierce (1996) suggest involving the students in assessing their writing. One way to involve students in writing assessment is through peer assessment by which students 
respond other's writing as they participate in their writing conferences. Peer assessment can be defined as a response in some forms to other learner's work. It can be given by a group or an individual (Puhl, 1997:8). To conduct this kind of assessment the teacher need to show the writing sample to students, and together with the students generate criteria for assessing it. From the clear criteria the students can see the relationship between what they have written and the grade they receive so that it can encourage them to take more responsibility for their own learning. They learn about qualities of good work and extend their own opportunities to learn how to write so that the mystery surrounding the definition of good writing was removed (Stiggins, 1994)

Involving students in their own assessment is critical. By reflecting on and assessing their own work and their peers', they get the opportunity to apply the criteria for the work and to set the learning goal. In this case, Puhl (1997) reminds that in giving responses, the assessors have to be guided by the teacher and negotiated with other learners before the work is started so that assessors can find a direction for their feedback.

A study about peer assessment in groups works conducted by Bulman (2002) reveals that peer assessment forms work as a release valve. Students said that knowing they would evaluate their peers and be evaluated by their peers made them work harder on the project than they might if their grade only were at stake. Furthermore, Tickoo's (1995) action research on peer review found that through peer assessment students could develop their critical skills, they had immediate feedback to check communication, they had access to a wider audience and it also decreased workload for the teacher. Even this study showed that the students were very much interested in doing the activity.

There is always a question that might appear about the ability of learners who are still in the process of acquisition, especially the early processes to render an accurate assessment of their own performance. Nevertheless, a closer look at the acquisition of any skills reveals the importance, if not the necessity, of selfassessment and the benefit of peer-assessment. Brown (2004) states that a successful learner actually has developed the ability to monitor his or her own performance and to use the data gathered for adjustment and corrections. Most successful learners extend the learning process well beyond the classroom and the presence of a teacher or tutor, autonomously mastering the art of self-assessment. Where peers are available to render assessments, the advantage of such additional input is obvious.

The writer had done such a preliminary study in order to identify the real problems the students and the teachers encountered in the teaching of the writing skill. It can be assumed that the unsuccessful result of the teaching writing skill in this school might be caused by assessment problems. There was very limited writing practice offered to the students, and it certainly affected their writing skill. Further, it was because the teachers had difficulties in finding and implementing an appropriate assessment strategy to assess and improve the students' writing skill. In addition, the teachers never gave the students a chance to render an assessment in writing and as a result the students had never known the criteria of a good piece of writing and had no chances to get and give response and make changes on their work before it was submitted. In the try out of the peer assessment strategy, it was found that some students showed the ability to respond and identify mistakes in spelling, punctuation, capitalization and grammar (subject-verb agreement, certain pronouns and certain plural forms) on their peer's work meaning that no doubt about the ability and maturity of SMP students to be involved in this alternative assessment strategy.

The reasons and findings above lead to the idea to conduct a study to implement an appropriate strategy of peer assessment in writing instructions of SMP students in order to improve the students' writing ability. This study is based on the assumption that peer assessment will provide students with a chance of making greater gain in their writing quality and further to improve their writing ability. Therefore, without neglecting teacher assessment, it is expected to serve as a supplementary assessment in writing instructions of SMP students.

In line with the background of the study, the research problem can be formulated in a question as follows; "How can peer assessment strategy be implemented to improve the writing ability of the second year students of SMPN 44 Muaro Jambi?"

\section{RESEARCH METHODOLOGY}

The design of this study belongs to Classroom Action Research (CAR) designed to implement an appropriate strategy of peer assessment in writing instructions for the second year students of SMPN 44 Muaro Jambi in order to improve the students' ability in writing a descriptive paragraph. It is also designed for English teachers who want to involve students in an alternative assessment strategy and implement the assessment as an integral part of the teaching and learning process.

The procedure was done by using the model of Kemmis and Taggart (in Suyanto and Sukaryana, 2001) which consists of four steps. They are planning an action, implementing the action, observing, and reflecting.

The subjects of the study were the second year students of SMPN 44 Muaro Jambi of the second semester of 2005/2006 academic year. The selected class was Class II cempedak that consists of 23 students, and in order to have more intense data, six (6) students were selected as the focused subjects of this study. These students were all from the average level and in order for the researcher to analyze the data more easily; they were 
put in such a way that each of them assessed their peer's work reciprocally.

The study was conducted by following the procedure of the classroom action research; after identifying problems in the preliminary study, the research was started from planning the action, followed by implementing the action, observing, and evaluating or reflecting.

In relation with the implementation of action research, the researcher made some preparation in order to find and implement an appropriate strategy of peer assessment in writing instructions for SMP students. The preparation includes: (1) setting out the procedure, (2) developing the main instrument of peer assessment, (3) designing lesson plans, (4) selecting writing tasks/activities, (5) specifying the criteria of success, and (6) developing research instruments.

In implementing the action, the researcher or the teacher did several procedures in the teaching and learning process that covers three sessions. They were (1) training session, (2) modeling session, (3) Peer assessment process.

Briefly, the researcher or the teacher describes the procedures of applying peer assessment in guidelines that are presented in Table 1 .

\begin{tabular}{|c|c|c|c|}
\hline Session & $\begin{array}{l}\text { Peer Assessment } \\
\text { Procedures }\end{array}$ & Teacher's Activities & Students' Activities \\
\hline $\begin{array}{l}\text { MODELLING } \\
\text { SESSION }\end{array}$ & $\begin{array}{l}\text { 1. Giving clear and } \\
\text { detailed guidelines } \\
\text { 2. Building students' } \\
\text { self confidence to } \\
\text { write and assess }\end{array}$ & $\begin{array}{l}\text { - prepares clear examples of PA checklists } \\
\text { - discusses the examples } \\
\text { - defines the task clearly } \\
\text { - has the students write from tracing activity } \\
\text { - has the students conduct the assessment activity } \\
\text { from the simple aspects of writing conventions } \\
\text { - encourage the students to answer and solve by } \\
\text { themselves any questions that might appear } \\
\text { - monitors and guides the students } \\
\text { - applies group conferences with the students }\end{array}$ & $\begin{array}{l}\text { - study the examples of PA } \\
\text { checklists } \\
\text { - write, assess, and rewrite } \\
\text { their work } \\
\text { - answer questions } \\
\text { - do efforts to solve their } \\
\text { problems } \\
\text { - participate in group } \\
\text { conferences } \\
\text { - try to solve their problems }\end{array}$ \\
\hline
\end{tabular}

\begin{tabular}{|c|c|c|c|}
\hline $\begin{array}{l}\text { PEER ASSESS- } \\
\text { MENT } \\
\text { PROCESS }\end{array}$ & $\begin{array}{l}\text { 3. Encouraging } \\
\text { students' self } \\
\text { confidence to write } \\
\text { and assess } \\
\text { 4. Ensuring follow up } \\
\text { tasks }\end{array}$ & $\begin{array}{l}\text { - prepares writing prompts. } \\
\text { - has the students write } \\
\text { - has the students conduct the assessment activity } \\
\text { - encourage the students to answer and solve by } \\
\text { themselves any questions that might appear } \\
\text { - monitors and guides the students } \\
\text { - has the students do self assessment } \\
\text { - applies continuously conferences with the } \\
\text { students } \\
\text { - assesses the students writing using the } \\
\text { instrument prepared }\end{array}$ & $\begin{array}{l}\text { - study the writing prompts } \\
\text { - write, assess, and revise } \\
\text { their work } \\
\text { - answer questions } \\
\text { - do efforts to solve their } \\
\text { problem } \\
\text { - do self assessment } \\
\text { - participate in conferences } \\
\text { - submit their work }\end{array}$ \\
\hline
\end{tabular}

In the observation stage, the researcher observed and collected the data about any aspect or event that happened during the implementation of the action in relation with the target or the criteria of success of this study. The observer observed the teaching and learning and the assessment process focusing on the activities done by the teacher and the students. All their activities during the implementation of the peer assessment strategy were recorded using the instruments that have been previously developed. The data of this study were also in the form of the subjects' scratches on their peer's responding and editing form, the subjects' answers on the interview guidelines and the grades on the students' rewritten works. Briefly, the researcher observed whether the peer assessment procedures worked effectively in the writing process of SMP students and can be used to improve the students' ability in writing a descriptive paragraph. The results the observation that had been analyzed provided as the basis for considering that the peer assessment strategy implemented can be used to improve the students' ability in writing a descriptive paragraph.

All the data gathered from the result of all the instruments used, were analyzed using qualitative analysis. The qualitative data were presented in a numerical form as a simple statistical analysis was also used.

In the reflection stage, the researcher reflected what had been done in the previous action. In this case, the researcher decided whether the effect of the action had met the criteria of success. The implementation of the action was successful when all the criteria of success of this study had been reached. 


\section{DATA PRESENTATION AND DISCUSSION}

This section provides the students' feeling toward the implementation of peer assessment in writing instructions and the assessment process done by the students.

In order to record the students' feeling toward the implementation of peer assessment of writing in classroom application, the researcher then provided the subjects with interview guidelines. Each subject had to respond and answer the questions that were presented in Bahasa Indonesia.

Based on the subjects' answers on the interview, it was found that they felt happy, comfortable, and enthusiastic of accepting the implementation of this alternative assessment strategy. Even though it was something new for them, they admitted that they did not mind accepting any correction from their peers on their writing. The subjects said that they found their peers could be trusted in assessing their works. They also felt comfortable and secure perceiving that their peers could give much contribution toward the improvements of their writing and learning as well. The subjects felt happy because by the implementation of this assessment strategy, they were given chances to share and help each other in accomplishing their work and further, in having better writing product before it was given score or grade. One important point, they perceived the principles of collaborative work or learner centred. One of them even gave a very interesting answer toward one question as he said that he had never realized before of the capability of his peers to become his learning source. He said that for so long he had treated his peers as rivals and always thought of competitiveness in accomplishing any tasks from teachers.

In general, the students acknowledged that they enjoyed learning because they got new experience as they were given chances to be involved in the assessment process. They were given step-by-step writing activities from the tracing up to the composing activity. They were given step- by-step guidance of conducting this alternative assessment strategy. They were given chances to share with others and to have better final writing products. They could see their own weaknesses, strength, and progress in writing, and they were happy because their grades were also attained from many sources, not only from tests.

In order to explore the students' reaction toward the procedures implemented, the teacher also asked questions. In response to the questions, all of the subjects gave positive reaction. It was apparent that the subjects felt that what they had done in the training and the modelling session had been very much helpful in preparing them to have the real peer assessment process. They said that it had led them to be more careful, responsible, and excited in accomplishing the tasks. They also said that it had encouraged their self-esteem and their willingness to share with others.
This part is devoted to the assessment activity done by the students. All data were collected from the subjects' peer's worksheet before rewriting and the peer responding and editing form for writing assessment. Following is the description of the assessment activity done by ES, IG, GY, FY, FA, and CI.

ES' ability to assess was collected from the data taken from IG's worksheets before rewriting and peer responding and editing instruments. She could recognize the mistakes on spelling, the use of proper punctuation, and the use of certain subject verb agreement as mistakes made by IG on IG's works. She could also respond her peer's writing as well as conducting the assessment activity using the instruments prepared properly.

As they had assessed their work reciprocally, the description of the assessment done by IG is taken from ES' worksheets and instruments. IG showed the ability to recognize the mistakes on spelling, the use of proper punctuation, the use of certain personal and possessive pronouns, the use of certain subject verb agreement, the use of past form, and certain plural form as mistakes made by ES on ES' writing. She also had responded her peer's work using the instruments well.

GY's ability to assess was derived from the scratches he made on FY's works and peer responding and editing formats. He was able to correct the mistakes on spelling, the use of adverb of time, the use of certain subject verb agreement, and the use of noun phrase as mistakes made by FY. He could also respond his peer's work using the formats well.

FY's ability to assess his peer's work was collected from the data taken from GY' worksheets and instruments. He could be aware of the mistakes on spelling, the use of personal and possessive pronoun, the use of proper punctuation and the use of subject verb agreement as mistakes made by GY. FY also had responded GY's works using the instruments provided properly.

The description of the assessment done by FA was derived from the data taken from CI's worksheets and instruments. She was able to recognize the mistakes on spelling, the sentence structure, the use of capitalization, and the use of certain subject verb agreement as mistakes found on CI's works. FA also had responded her peer's writing using the instruments prepared properly.

CI's ability to assess her peer's works was collected from the data taken from FA's worksheets and peer responding and editing formats. She had responded her peer's writing as well as using the formats properly and was able to recognize the mistakes on spelling, the use of certain subject verb agreement, the use of proper punctuation, and plural forms as mistakes made by FA on FA's works.

To see whether the action was successful or not, the researcher did reflection. The reflection was focused on the analysis of the peer assessment procedures imple- 
mented, the assessment activity done by the students, the students' writing products, and the learning results.

The procedures are considered to be successful and applicable if they run effectively in the writing instructions of SMP level. Precisely, the procedures facilitate the students to be actively involved in the instructional activity and assessment process. The indicators of proving that the students are actively involved in the instructions and assessment process are stated in the observation checklist toward the students' activities and are recorded in field notes.

Based on the analysis on the observation checklist toward the students' activities and field notes, it was found that most of the students had done the writing tasks given seriously and carefully and could handle the assessment activity well. Even though in the early meeting all students looked worried, shy and not confident to assess their peer's work involving their own knowledge of writing conventions and grammar, gradually, because the procedures had facilitated them to have easy tasks, they showed willingness to trust each other and further it increased their ability to share and assess each other. The inquiry process that was always built among the students in solving their problems had also been successful in leading the students to handle this alternative assessment strategy well. Based on the data obtained, the students even could handle the assessment activity using the instruments prepared properly. Generally, the data obtained had also proved that the target of the implementation had been achieved, except about the ability of the students to assess their peers' work involving their own knowledge and to do self- assessment, because not the entire class could do it. However, it is believed to increase among all of the students as they keep on doing peer assessment, and become more reflective in accomplishing their writing tasks and in assessing their own works.

The assessment done by the students was analysed by comparing the results of the peer's feedback with the samples of the subjects' mistakes found on their writing. The analysis was focussed on certain aspects of assessment as stated in the limitation of this study. In order to make the analysis more clearly, four categories of criteria were established to judge the peer's feedbacks. The best category is A which refers to very good. This category is assigned when the feedback accords with the target. The next category is B refers to good, when the feedback gets closed with the target. C refers to fair, when the feedback digresses from the target. D refers to poor, when there is no feedback. The analysis was also made on the basis of each subject's ability to give useful feedback on his or her peer's work. One of the sample is described on the Table 4.1 that presents the sample of the feedback given by their peer toward the subject's writing.

On the basis of the analysis of the assessment done by the subjects, it was found that all of them had shown the ability to give useful feedbacks on their peer's work even though it is only on the certain aspects of writing conventions and grammar. Dealing with the unexpected mistakes the subjects had made and the expected feedbacks they should give to their peers but they didn't, all of them gave the same answers that some because of being careless, and the rest because of the limited knowledge of writing conventions and grammar they possessed.

An analysis was also done by looking at the subjects' ability to assess their peer's works using the instruments prepared. The analysis was done by comparing the subjects' works before rewriting to the subjects' peer responding and editing form for writing assessment that had been filled in by their peers. It revealed that all of the subjects had shown the ability to assess their peer's writing products using the instruments prepared properly.

The Samples of the Feedback given by ES toward IG's Writing

\begin{tabular}{|c|c|c|c|c|}
\hline No & $\begin{array}{l}\text { Types of Mistakes identified } \\
\text { on IG's works }\end{array}$ & Samples of Mistakes & The Peer's Feedback & $\begin{array}{l}\text { The Feedback } \\
\text { Category }\end{array}$ \\
\hline \multirow[t]{3}{*}{1} & Spelling writing & $\begin{array}{l}1 \ldots \text { she is beautiful, smart, } \\
\text { and energitic }\end{array}$ & $\begin{array}{l}1 \ldots \text { she is beautiful, smart and } \\
\text { energetic }\end{array}$ & A \\
\hline & & $2 \ldots$ my body is rilex & $2 \ldots$ my body is relax & $\mathrm{B}$ \\
\hline & & $3 \ldots$ and sometime & $3 \ldots$ and sometimes & A \\
\hline \multirow[t]{3}{*}{2} & The subject verb agreement & 1. Her eyes is beautiful & 1. Her eyes are beautiful & A \\
\hline & & $2 \ldots$ she also play in sinetron & 2. No feedback & $\mathrm{D}$ \\
\hline & & $3 \ldots$ there $i$ s some fish & $3 \ldots$ there are some fish & A \\
\hline 3 & $\begin{array}{l}\text { The use of proper punctuation } \\
\text { or capitalization }\end{array}$ & $\begin{array}{l}\text { 1. In the fish pond There is } \\
\text { some fish }\end{array}$ & $\begin{array}{l}\text { 1. In the fish pond there are some } \\
\text { fish }\end{array}$ & A \\
\hline
\end{tabular}

The students' writing products were also collected, graded and analysed by the researcher. The analysis then focused on the selected subjects' writing products. Each subject had six writing products to be analysed, three before rewritten products and three after rewritten products. All were then graded using the holistic scoring rubric for writing assessment and were analysed using a simple statistical analysis to know whether the criteria of success had been reached. The analysis was done by comparing the before rewritten 
products to the after rewritten products. The improvement at least one point level on the quality of the students' rewritten works indicates that their peer's feedback has been very much helpful in increasing the quality of their rewritten products, meaning that they get benefits from sharing each other. Table 4.2 presents the data collected from the subjects' before and after rewritten products.

The students' rewritten works were all collected, graded, and analysed by the researcher in order to reflect the improvements the students had reached dealing with their ability to write a descriptive paragraph. All of the students' rewritten works were graded based on the holistic scoring rubric developed by the researcher. The results had shown that the average (the mean) of the students' grades in writing a descriptive paragraph had increased up to the targeted grades (at least 8 of the range that lies from 5 to 10 ). Table 4.3 presents the simple descriptive statistics of the grades. Table 4.2 Data Collected from the Subjects' before and after Rewritten Products

\begin{tabular}{|c|c|c|c|c|c|c|c|c|c|}
\hline \multirow{3}{*}{ Name } & \multirow{3}{*}{ Scorer } & \multicolumn{6}{|c|}{ Assignment } & \multirow{2}{*}{\multicolumn{2}{|c|}{ Mean }} \\
\hline & & & & & & & & & \\
\hline & & Before & After & Before & After & Before & After & Before & After \\
\hline \multirow{2}{*}{ Es } & A & 7.50 & 8.50 & 8.00 & 8,60 & 7,50 & 8,90 & 7,67 & 8,67 \\
\hline & B & 7,00 & 8,20 & 8.00 & 8,50 & 7,50 & 8,80 & 7,50 & 8,50 \\
\hline \multirow{2}{*}{ Ig } & A & 7.50 & 8,30 & 7,50 & 8,90 & 8.00 & 9.00 & 7,67 & 8,73 \\
\hline & B & 7,50 & 8.50 & 7,60 & 8,80 & 8.50 & 9.30 & 7,87 & 8,87 \\
\hline \multirow{2}{*}{ Gy } & A & 6.50 & 7,00 & 8.00 & 9.50 & 8.50 & 9.50 & 7,67 & 8,67 \\
\hline & B & 6,30 & 7,00 & 8.10 & 9.50 & 8.50 & 9.50 & 7,63 & 8,67 \\
\hline \multirow{2}{*}{ Fy } & A & 6,50 & 7,50 & 7,00 & 8,20 & 7,80 & 8,60 & 7,10 & 8,10 \\
\hline & B & 6,20 & 7,50 & 6,90 & 8,00 & 7,50 & 8,50 & 6,87 & 8,00 \\
\hline \multirow{2}{*}{$\mathrm{Fa}$} & A & 6,80 & 7,20 & 7,00 & 9.00 & 7,50 & 8,20 & 7,10 & 8,13 \\
\hline & B & 6,50 & 7,20 & 7,10 & 9.00 & 8.50 & 9.40 & 7,30 & 8,53 \\
\hline \multirow{2}{*}{$\mathrm{Ci}$} & A & 8.00 & 9.00 & 8.00 & 9.20 & 7,90 & 9,20 & 7,97 & 9,13 \\
\hline & B & 8.20 & 9.30 & 8.00 & 9.50 & 8,00 & 9,50 & 8,07 & 9,43 \\
\hline
\end{tabular}

The findings and the analysis or the reflection of the process and the products in the cycle made by the researcher, then lead to the conclusion that she had already implemented the appropriate strategy of peer assessment in writing instructions in order to improve the students' ability in writing a descriptive paragraph. Since all the criteria of success of this study had been achieved and due to the limited time, the action then was stopped. However, in reality, the strategy is kept on doing in the class. Dealing with the ability of the students to assess involving their own knowledge, it is believed to increase as they become more careful and reflective in accomplishing their writing tasks and in assessing their own works. Table 4.3. Simple Descriptive Statistics of the Students' Grades

\begin{tabular}{llllll}
\hline & N & $\begin{array}{l}\text { Mini } \\
\text { mum }\end{array}$ & $\begin{array}{l}\text { Maxi } \\
\text { mum }\end{array}$ & Mean & $\begin{array}{l}\text { Std. } \\
\text { Deviation }\end{array}$ \\
\hline Pre-Test & 39 & 5.00 & 8.00 & 6.1385 & .78325 \\
Assignment 1 & 39 & 6.00 & 9.30 & 7.5282 & .89353 \\
Assignment 2 & 39 & 6.50 & 9.50 & 8.2692 & .69060 \\
Assignment 3 & 39 & 6.50 & 9.50 & 8.4154 & .65676 \\
\hline
\end{tabular}

This part discusses the peer assessment procedures implemented that improve the students' ability in writing a descriptive paragraph. In the discussion about the procedures, all the elements that had been proved effective and applicable in the writing instructions at the second year students of SMPN 44 Muaro Jambi are presented.
Peer assessment is a process that many students, especially those in traditional educational system will initially find uncomfortable and insecure. For so long the students believe that a teacher is the only person who can help them achieve their learning target. They have never realized that the presence of their friends will affect and give something great toward their learning achievement. Therefore, telling the purpose of conducting peer assessment is something important to be done at the very beginning in order the students perceive that each of them has a particular capability to help their friends, and if they know the way to share it, it will lead them to success.

Peer assessment is not merely an assessment tool but also one arm of a plethora of tasks and procedures within the domain of learner centred and collaborative education (Brown, 2004). This concept then leads to the decision to group the students in accomplishing the tasks given both in conducting the assessment process using the instruments developed and making improvements on their writing products. In the implementation of peer assessment, collaborative work has worked in helping the students identify issues and explore solutions by themselves.

One of the greatest drawbacks to peer assessment is the threat of subjectivity (Brown, 2004). Therefore, establishing clear assessment criteria is very important done before having the students conduct it. Clear assessment criteria can go a long way toward encouraging objectivity. Before coming to the action, the 
researcher and the students have already generated the criteria of how their writing will be assessed. This results instruments that the students use when they assess their peer's writing. From the clear criteria the students could see the relationship between what they have written and the grade they receive. Encouraging impartial assessment also leads the students to the advantages of honest and objective opinions.

Unfamiliar ways of teaching and assessment are potential in making the students feel insecure and threatened. Peer assessment is a new strategy developed and implemented in writing instructions at SMP level, therefore, it is important for the teacher to define the task clearly and have the students know what they were supposed to do before having them do that. Peer assessment is a strategy or way students may use when they respond to their friends' work. In order to help the students understand better of conducting the assessment activity using the instruments prepared, the teacher provide the students with clear examples. The examples have been proved to serve as a reference when the students assess their peer's work.

The implementation of peer assessment is something new for the students. They still have no idea about the purpose of conducting it. However, when they have the idea, they do not feel confident about their capability of using their own knowledge and talents to be achievers. They also have no idea about the way to collaborate by which they benefit from one another or in mutual respect. Therefore, the teacher invites the students to be involved in activities starting from the activity that could be done by each student at that level. The teacher has the students write from the tracing activity in order they have a chance to gradually learn the basic conventions of writing.

Having the students go through the step-by-step writing activities from tracing up to composing activity, are also indirectly invites them to be involved in the step-by-step assessment activities. For this reason, the instruments the students use when they assess their friend's work are designed different depending on the aspects to be assessed. All is done to convince the students that they can handle it successfully, to minimize the students' frustration and the most important point, to build the students' confidence and self esteem about their own capability of being their peers' learning source.

The successful result of what the students do in the previous event can motivate the students to continuously do it. They have already been involved in a new strategy and have found that how well they share could lead them to become achievers. There is a great possibility that they want to exhibit it again. It is challenging for them. The teacher then uses these opportunities to put the students in the real peer assessment process. The students begin to write their own ideas guided by some clues and provided with writing prompts and then have to assess their peer's work using a more difficult instrument. The writing activities and the assessment process the students do then serve much as a reinforcement of what they have already done in the previous meetings. Step-by-step writing activities and assessment process the students do, have helped them build and encourage their selfconfidence to write and assess.

According to Brown (2004), it is not enough to simply toss checklists at students and then walked away. As certain subject matters without a follow up guidance may result nothing, the implementation of peer assessment procedures should also be ensured with follow up tasks. The follow up tasks could be in the form of having the students do self assessment, doing a conference with the students, giving written feedback toward the students' work, and giving grades on the students' work. By ensuring that follow up tasks are always done, it supports the successful result of the implementation of peer assessment strategy.

\section{CONCLUSSIONS AND SUGGESTIONS}

On the basis of the research findings conducted, there are some conclusions can be drawn as the answers of the research questions.

The appropriate strategy of peer assessment to improve the students' ability in writing a descriptive paragraph requires teachers to follow procedures; telling the purpose of conducting peer assessment, encouraging collaborative work, encouraging impartial assessment, giving clear and detailed guidelines, building students' self confidence to write and assess, encouraging stus' self confidence to write and assess, and ensuring follow up tasks.

The peer assessment implemented has the teacher follow some activities. In the initial activity, the teacher tells the purpose of conducting peer assessment by introducing the concept of learner centred and collaborative education, then followed by putting the students in groups. After that, the teacher has the students study the criteria of how their writing will be assessed by distributing the peer responding and editing form for writing assessment and the holistic scoring rubric. In having the students conduct peer assessment, the teacher provides the students with clear examples of peer assessment checklists and then gives them chances to have step-by-step writing activities from the tracing up to the composing activity and step- by-step guidance of conducting peer assessment strategy. The teacher then also gives the students chances to share with others and to rewrite their work in order for them to have better final writing products. Finally, the teacher grades the students' writing using the instrument prepared and keeps on doing conferences with the students, particularly with the less able ones.

The strategy implemented has functioned as an assessment tool because it has facilitated the teacher to 
have information about the students' performance in writing. As a part of alternative assessments, it also allows the students to be assessed on what they normally do in class everyday; it taps into problem solving skills; it provides information about both the strengths and weaknesses of the students in writing; and it brings the students to self-reflect and self-assess.

The peer assessment implemented has also promoted the notion of learner centred and collaborative education. The students are given chances to be actively involved in assessing their own works, nurtured as inquirers, and led to be autonomous learners. The students realize that a teacher is not the only person they could trust to help and teach them and that they have changed their mind as they begin to treat their peers not as rivals but as one of their learning sources. The students start to think that collaboration results something greater than what any single part could achieve. They learn to respect and help others.

The strength of the strategy implemented is its effectiveness in assessing the students' writing skill. Teachers may give the students a lot of writing practices and assignments and get many samples of the students' writing that could become the basis of examining the students' progress without involving too much time and burden of assessing it. Further, the peer assessment implemented has also improved the students' ability in writing a descriptive paragraph.

The weakness of the strategy implemented revolves around the practicality that the preparations can be time and efforts consuming.

For the research findings need to be followed up, some suggestions are also addressed to, the teachers, the students, and the school principal or government, and to future researchers.

\section{To the Teachers}

Regarding that the peer assessment strategy can effectively assess and improve the students' writing, English teachers are recommended to apply this strategy in writing instructions at SMP level by also considering their students' level and the designs of the lesson plans. Further, The teachers are suggested socializing the peer assessment strategy in teachers' forum such as workshops, in-service trainings, seminars, and Musyawarah Guru Mata Pelajaran (MGMP).

\section{To the Students}

Referring to the advantages of peer assessment toward the students' learning attitude that could lead them to become more responsible, responsive and reflective, the students are then suggested keeping on doing peer assessment not only in English class but also in learning other subjects. They are also suggested collecting their works in portfolios in order they can see their progress over time.

\section{To the School Principal or the Government}

Implementing peer assessment in instructions no doubts needs an extra investment of time, efforts, and money that easily result negative responses from teachers and/or students, especially from teachers who are not creative and innovative. Therefore, training programs or workshops need to be conducted by the government or educational organizations to help teachers understand the benefits of implementing peer assessment in foreign language teaching and assessment. The principal or the government should also consider that the trainings or workshops would become media for teachers to learn about peer assessment as classroom practices.

\section{To Future Researchers}

This study is an action research in which the result is very typical and cannot be generalized, so that it is advisable that future researchers carry out a study of peer assessment at the same or higher level to verify the strength of this model in assessing and improving the students' writing ability. It is also suggested that they conduct action research to implement an appropriate and applicable strategy of peer assessment in assessing and improving other language skills; listening, reading, and speaking.

\section{REFFERENCES}

Brown, H.D.2004. Language Assessment: Principles and Classroom practices. San Francisco: Longman.

McLaughlin. M and Vogt M.E. 1996. Portfolio in Teacher Education. California. International Reading Association.

Mukminatien, N. 1997. The Differences of Students' Writing Ability Achievements Across Different Course Level. Dissertation. IKIP Malang.

O' Malley, M.J. \& Pierce.V.L. 1996. Authentic assessment for English Language

Learning. Practical Approach for Teacher. White plains, New York: Addison Wesley.

Puhl, C. A. 1997. Develop, Not Judge. Continuous assessment in ESL Classroom. English Teaching Forum, April 1997.

Richards J. C. Renandya, W.A. (Eds.) 2002. Methodology in Language Teaching: An Anthology of Current Practice. Cambridge: Cambridge University Press.

Stiggins, R.J. 1994. Students-Centered Classroom Assessment. New York: Merrill.

Stone, J.M. 1990. Cooperative Learning and Language Arts: A Multi Structural Approach. University of California, Riverside.

Suyanto, K. K. E \& Sukaryana, I. W. 2001. Penelitian Tindakan Kelas. Malang: Penerbit Universitas Negeri Malang. 
Abdul Khalim, Implementing Peer Assessment to Improve the Writing Ability of the Second Year Students of Smp Negeri 44 Muaro Jambi

Tickoo, M. L. !995. Reading and writing: Theory into Practice. Anthopology Series 35 Singapura: SEAMEO Regional Language Centre.

Tierney R J. et al. 1991. Portfolio Assessment in the Reading-Writing Classroom. Norwood, Massachusetts: Christoper-Gordon.

Wallace. et al.1978. Educational Assessment of Learning Problems: Testing for Teaching. New Jersey: Allyn and Bacon 